\title{
PENERAPAN BENTUK MEDIASI PENAL DENGAN PENDEKATAN KEADILAN RESTORATIF DALAM SISTEM PERADILAN PIDANA ANAK
}

\author{
Candra Ulfatun Nisa \\ Fakultas Hukum, Universitas Diponegoro, Semarang \\ Email: candraulfatun@gmail.com \\ Nyoman Serikat Putra Jaya \\ Fakultas Hukum, Universitas Diponegoro, Semarang \\ Email : putrajaya1984@yahoo.co.id
}

\begin{abstract}
Abstrak
Sistem peradilan pidana anak wajib menggunakan pendekatan keadilan restoratif dengan melalui diversi. Diversi dalam penyelesaian perkara anak adalah proses peradilan pidana yang dialihkan ke proses di luar peradilan pidana. Jurnal ini difokuskan pada bentuk penerapan mediasi penal sekaligus pembatasan pemberlakuannya dalam sistem peradilan pidana anak yang diatur dalam Undang-Undang Nomor 11 Tahun 2012 Tentang Sistem Peradilan Pidana Anak. Metode pendekatan yang digunakan adalah yuridis normatif, dengan spesifikasi penelitian deskriptif. Hasil penelitian ini adalah bahwa sistem peradilan pidana anak mengandung pengertian bentuk mediasi penal, dengan dua pendekatan yakni victim offender mediation dan restorative conferencing yang meliputi family group conference.
\end{abstract}

Kata Kunci: mediasi penal, keadilan restoratif, diversi.

\section{Abstract}

The juvenile justice system must use the restorative justice approach through diversion. Diversion in the settlement of child cases is a criminal justice process that is transferred to processes outside of criminal justice. This journal is focused on the application of penal mediation as well as restrictions on its application in the juvenile criminal justice system which is regulated in the Law Number 11 Year 2012 on the Juvenile Justice System. The method of research using the normative juridical approach, with descriptive research specifications. The results of this study are that in the juvenile criminal justice system contains the notion of mediating penal, with two approaches namely victim offender mediation and restorative conferencing which includes family group conference.

Keywords: penal mediation; restorative justice; diversion

\section{Pendahuluan}

Maraknya kejahatan yang kerap terjadi akhir-akhir ini tidak hanya dilakukan oleh orang dewasa saja tetapi juga dilakukan oleh anakanak baik secara sendiri-sendiri, maupun secara bersama-sama. Anak sebagai pelaku tindak pidana sebenarnya tidak murni sebagai pelaku saja, namun pada dasarnya juga merupakan korban. Hal itu disebabkan, karena ada beberapa 
faktor penyebab yang paling berpengaruh dalam terjadinya tindak pidana anak diantaranya adalah faktor lingkungan baik itu lingkungan keluarga maupun lingkungan masyarakat. Terdapat pula faktor lain yang tidak kalah berpengaruh terhadap proses tumbuh kembang anak yakni seperti faktor sosial, ekonomi dan budaya.

Mengenai proses hukum dan penjatuhan pidananya, tentu sangat tidak adil apabila anak dipersamakan dengan terdakwa dewasa, sehingga dalam menanangani tindak pidana yang dilakukan oleh anak, harus benarbenar memperhatikan kepentingan dan masa depan anak demi meneruskan cita-cita perjuangan bangsa (Burhanuddin, 2019).

Anak masih mengalami proses dalam hal perkembangan fisik, mental dan psikis, maupun sosial menuju kesempurnaan seperti orang dewasa. Akibat dari itu, reaksi yang diberikan kepada anak tidak sama dengan reaksi yang diberikan orang dewasa, yang lebih mengarah kepada punitive (Nashriana, 2012). Adanya perbedaan dalam hal penjatuhan pidana kepada anak tersebut bertujuan untuk memberikan kesempatan agar setelah melalui pembinaan akan memperoleh jati dirinya untuk menjadi manusia yang lebih baik, yang berguna bagi diri, keluarga, masyarakat, bangsa dan Negara (Soetedjo, 2010).

Sehubungan dengan hal tersebut, diselenggarakanlah sistem peradilan pidana anak. Sistem peradilan pidana anak dalam hal penjatuhan sanksinya terfokus untuk tujuan sebagai sarana untuk mendukung kesejahteraan anak pelaku tindak pidana.

Sistem peradilan pidana Indonesia dalam perkembangannya telah menggunakan konsep keadilan restoratif dalam penyelesaian perkara pidananya. Keadilan restoratif ini pada hakikatnya bertujuan untuk memulihkan kembali pada keadaan semula seperti saat sebelum terjadinya tindak pidana dengan menggunakan pendekatan yang lebih menitikberatkan pada kondisi terciptanya keadilan dan keseimbangan bagi pelaku maupun korbannya sendiri (Chandra, 2014). Selain itu juga menempatkan pelaku, korban, dan masyarakat sebagai "stakeholders" yang bekerja bersama dan langsung berusaha menemukan penyelesaian yang dipandang adil bagi semua pihak (win-win solutions) (Manan, 2008). Pendekatan yang dimaksud harus mampu menembus ruang hati dan pikiran para pihak yang terkait dalam proses penyelesaian suatu perkara untuk memahami makna dan tujuan dilakukannya suatu pemulihan dan sanksi yang diterapkan adalah sanksi memulihkan seperti saat sebelum terjadinya tindak pidana dan bersifat mencegah (Hutahuruk, 2013).

Undang-Undang Nomor 11 tahun 2012 tentang Sistem Peradilan Pidana Anak (selanjutnya disingkat UU SPPA) Pasal 5 ayat (1) dengan tegas menyebutkan bahwa wajib terlebih dahulu mengupayakan pendekatan keadilan restoratif dalam setiap menangani perkara 
tindak pidana yang terdakwanya anak.

Hal inilah yang membuat konsep keadilan restoratif diharapkan dalam sistem peradilan pidana anak berdasarkan beberapa pertimbangan tertentu dan tindak pidana ringan dengan tujuan untuk menghindarkan dari beberapa dampak buruk penjara dari prisonisasi hingga stigma buruk yang diberikan oleh masyarakat, mengingat tujuan keadilan restoratif adalah untuk perdamaian kedua belah pihak yang sempat rusak akibat terjadinya tindak pidana sehingga terjadi keseimbangan masyarakat.

Hakim harus dapat membuat putusan yang seadil-adilnya dengan mengedepankan model pemidanaan restorative justice, yaitu pemulihan kembali pada keadaan semula setelah peristiwa dan pemidanaan sebagai jalan akhir (ultimum remedium), sehingga perlu didahulukan cara lain di luar pengadilan. Proses peradilan pidana anak harus mengemukakan prinsipprinsip umum perlindungan anak, yaitu non diskriminasi, kepentingan terbaik bagi anak, kelangsungan hidup dan tumbuh kembang dan menghargai partisipasi anak.

Hal ini sesuai dengan pendapat M. Nasir Djamil mengenai anak yakni, anak harus diberikan bimbingan dan pembinaan, sehingga bisa tumbuh dan berkembang sebagai anak normal yang sehat dan cerdas seutuhnya, bukan justru sebaliknya untuk dihukum. Anak adalah anugerah Allah Yang Maha Kuasa yang diharapakan menjadi calon generasi penerus bangsa yang masih dalam perkembangan fisik dan mental. Situasi yang sulit terkadang membuat anak melakukan tindakan yang melanggar hukum. Meskipun demikian, tetap saja anak yang melanggar hukum tidak pantas untuk dihukum apalagi sampai dimasukan dalam penjara (Djamil, 2013).

Oleh karena itu, Negara mempunyai kewajiban untuk memberikan perlindungan khusus terhadap anak yang berhadapan dengan hukum. Perlindungan hukum bagi anak merupakan salah satu cara melindungi penerus bangsa di masa depan. Perlindungan ini diperlukan karena anak merupakan bagian masyarakat yang mempunyai keterbatasan secara fisik dan mentalnya.

Teori yang dipakai adalah teori penanggulangan kejahatan. Penanggulangan kejahatan dengan menggunakan hukum pidana pada dasarnya merupakan bagian dari usaha penegakan hukum pidana. Oleh karena itu, sering juga dikatakan, bahwa politik atau kebijakan hukum pidana juga merupakan bagian dari kebijakan penegakan hukum (law enforcement policy) (Arief, 2008).

\section{Perumusan Masalah}

Rumusan masalah berdasarkan uraian di atas yaitu bagaimana bentuk penerapan mediasi penal sekaligus pembatasan pemberlakuannya dalam sistem peradilan pidana anak yang diatur dalam UU SPPA?.

\section{Metode Penelitian}

Penulisan ini adalah hasil penelitian dengan menggunakan 
metode pendekatan yuridis normatif, dengan spesifikasi penelitian deskriptif (Disemadi \& Roisah, 2019). Data sekunder yang dikumpulkan dari bahan hukum primer, baik berupa ketentuan peraturan perundang-undangan dan pelaksanaannya; bahan hukum sekunder maupun bahan hukum tersier yang dilakukan melalui studi kepustakaan (Disemadi \& Roisah, 2019).

Penulisan ini menggunakan metode kualitatif, yaitu menguraikan data dalam bentuk kalimat yang teratur, runtun, logis, tidak tumpang tindih dan efektif dan kemudian dilakukan pembahasan. Berdasarkan hasil pembahasan diambil kesimpulan secara deduktif sebagai jawaban terhadap permasalahan yang diteliti, yaitu mengambil kesimpulan dari yang bersifat umum kepada hal-hal yang bersifat khusus.

\section{Pembahasan}

Secara umum pengertian keadilan restoratif adalah penataan kembali sistem pemidanaan yang lebih adil, baik bagi pelaku, korban maupun masyarakat (Manan, 2008). Selanjutnya, Bagir Manan mendefinisikan restorative justice adalah konsep pemidanaan, tetapi sebagai konsep pemidanaan tidak hanya terbatas pada ketentuan hukum pidana (formal dan materiil). Restorative justice harus juga diamati dari segi kriminologis dan sistem pemasyarakatan (Manan, 2008). Dari kenyataan yang ada, sistem pemidanaan yang berlaku belum sepenuhnya menjamin keadilan terpadu (intergrated justice), yaitu keadilan bagi pelaku, keadilan bagi korban dan keadilan bagi masyarakat. Hal inilah yang mendorong kedepan konsep restorative justice.

Bagir Manan menguraikan substansi restorative justice yang mengandung prinsip-prinsip yakni antaranya, meningkatkan partisipasi antara pelaku, korban dan kelompok masyarakat menyelesaikan suatu peristiwa atau tindak pidana. Menempatkan pelaku, korban dan masyarakat sebagai stakeholder yang bekerja sama dan langsung berusaha menemukan penyelesaian yang dipandang adil bagi semua pihak (win-win solution)(Manan, 2008).

Penyelesaian tindak pidana melalui pendekatan restoratif akan menjadi suatu realitas yang dapat diimplementasikan jika tidak dapat dibangun atau dikembangkan suatu model struktural dengan paradigma restoratif yang akan menjadi pilihan alternatif dalam sistem hukum pidana. Sehubungan dengan hal itu, menurut Van Ness sebagaimana yang dikutip oleh Rufinus Hotmaulana Hutauruk mempostulatkan beberapa model pendekatan restoratif sebagai pilihan alternatif yang dapat menggambarkan tempat dan kedudukan pendekatan restoratif dalam sistem hukum pidana, sebagai berikut:

a. Unified System

Kehidupan masyarakat yang sudah maju membuat masyarakat semakin sadar akan pentingnya kesetaraan dalam hukum. Negara telah mengambil alih konflik dari para pihak menjadikan suatu 
pilihan yang dapat memberi pandangan untuk menyisikan pendekatan restoratif menggantikan peradilan pidana. Untuk mengembalikan konflik itu ke "pemiliknya" yang berhak, memerlukan suatu pendekatan yang benarbenar berbeda dalam mengelola pemberian prosesproses keadilan, yang memungkinkan korban dan pelanggar dapat menentukan sendiri hasil penyelesaian konfliknya tersebut dan Negara tidak memiliki hak mutlak atas konflik yang dimaksud, sehingga berdasarakan pandangan ini proses-proses penyelesaian tindak pidana melalui pendekatan restoratif seharusnya dapat menggantikan semua proses dalam sistem peradilan pidana pada umumnya. Pandangan ini dapat diwujudkan dengan dua cara. Pertama, suatu sistem restoratif membuktikan dirinya mampu menangani semua kasus dan diberikan tanggung jawab tunggal untuk semua permasalahan tindak pidana. Kedua, sistem peradilan pidana kontemporer ditransformasikan melalui nilai-nilai baru dan dalam proses-proses ke dalam suatu sistem restoratif.

b. Dual Track System

Model dual track system ini dapat menjadi suatu pendamping alternatif bersama sistem peradilan pidana yang ada. Pada suatu model jalur ganda, proses restoratif dan tradisional akan berdampingan secara bersamasama, dimana para pihak yang menentukan wacana jalannya proses dari suatu kasus tertentu. Apabila kesepakatan sebagai proses alternatifnya tidak dapat dicapai oleh para pihak yang berkepentingan, sistem pengadilan peradilan pidana akan tetap tersedia. Jadi, dalam hal ini pendekatan restoratif ditempatkan menduduki posisi primer sedangkan lembaga-lembaga formal berperan sebagai suatu unsur pendukung. Pasal 5 ayat (1) Undang-Undang Nomor 11 Tahun 2012 tentang Sistem Peradilan Pidana Anak mengimplementasikan prinsip restorative justice dalam konsep dual track system ini yaitu dengan mendahulukan penyelesaian perkara pidana anak melalui prinsip restorative justice terlebih dahulu baru apabila tidak tercapai mufakat maka penyelesaian tindak pidana masuk ke pengadilan.

c. Safeguard System

Model ini adalah suatu model yang dirancang untuk menangani tindak pidana melalui pendekatan restoratif, dimana program-program restorasi akan menjadikan saran utama untuk menangani permasalahan-permasalahan tindak pidana. Hal ini berarti bahwa akan terjadi suatu peralihan besar dari sistem peradilan pidana pada umumnya yang akan mengalami reduksi ke sistem keadilan restoratif. Namun, 
untuk kasus-kasus tertentu akan tetap ditangani oleh sistem peradilan pidana kontemporer, yaitu kasuskasus yang dianggap tidak sesuai ditangani oleh suatu proses atau program restoratif.

d. Hybrid System

Model ini adalah suatu model di mana proses penentuan ataupun penetapan seseorang bersalah diproses dalam sistem peradilan pidana pada umumnya dan kemudian dalam proses penentuan sanksi maka konsep pendekatan restoratif dapat dipergunakan untuk menentukan jenis sanksinya. Menurut model ini baik respon pendekatan restoratif maupun respon peradilan pidana kontemporer dipandang sebagai bagian-bagian normatif dari sistem peradilan. (Hutahuruk, 2013)

Penggunaan pendekatan keadilan restoratif menurut Basic Principles PBB dapat menjadi bagian dari sistem peradilan pidana. Secara teoritis terdapat tiga model yang menempatkan hubungan keadilan restoratif dengan sistem peradilan pidana, yaitu:

a. Sebagai bagian dari sistem peradilan pidana

Sangatlah masuk akal jika restoratif sebagai suatu pemidanaan mengingat ciri dari pemidanaan adalah memaksa, menderitakan seiring dengan timbulnya rasa bersalah dan penyesalan dari dalam diri pelaku.

b. Di luar sistem peradilan pidana lembaga/institusi lain di luar sistem

Pandangan keadilan restoratif berbanding terbalik dengan sistem peradilan pidana yaitu mengharamkan sifat keras dari hukum pidana atau disebut sebagai soft justice karenanya dia harus berada di luar sistem peradilan pidana.

c. Di luar sistem peradilan pidana dengan tetap melibatkan pihak penegak hukum

Merupakan gambaran dari sistem quasi di mana titik berat di sini adalah bahwa model penyelesaian dengan pendekatan restoratif tetap harus berdampingan dengan sistem peradilan pidana karena pada dasarnya model penyelesaian ini dapat dijadikan dasar dari strategi penanganan perkara pidana yang tujuannya diarahkan pada kebaikan pelaku, korban dan masyarakat. Di samping itu hal ini juga menjadikannya sebagai bagian dari mekanisme yang sah dalam sistem hukum negara. (Retnaningrum, 2013)

Menurut Stephenson, Giller dan Brown ada empat bentuk mekanisme penyelesaian perkara melalui keadilan restoratif, yaitu:

a. Mediasi Penal (Victim Offender Mediation)

Mediasi penal merupakan sebuah proses penyelesaian perkara pidana dengan dibantu pihak ketiga yang netral dan imparisal, membantu korban dan pelaku untuk berkomunikasi satu 
sama lain dengan harapan dapat mencapai sebuah kesepakatan. Mediasi dapat terjadi secara langsung di mana korban dan pelaku hadir bersama atau secara tidak langsung di mana korban dan pelaku dengan difasilitasi oleh mediator (shuttle mediation(Retnaningrum, 2013).

Tujuan dilaksanakannya mediasi penal (victim offender mediation) adalah memberi penyelesaian terhadap peristiwa yang terjadi, di antaranya dengan membuat sanksi alternatif bagi pelaku atau untuk melakukan pembinaan di tempat khusus bagi pelanggaran yang benarbenar serius (Marlina, 2012).

b. Restorative Conference

Bentuk penyelesaian melalui restorative conference hampir sama dengan mediasi penal, yang membedakan hanyalah peran mediator sebagai pemandu diskusi, adanya naskah pemandu dan hadirnya pihak selain pelaku dan korban (yaitu keluarga dari masing-masing pihak).

c. Family Group Conferencing

Keluarga kedua belah pihak (pelaku dan korban) membuat sebuah rencana aksi (action plan) berdasarkan informasi dari pelaku, korban dan kalangan professional untuk membahas mengenai akibat yang ditimbulkan dari tindakan yang telah dilakukan sekaligus sebagai sarana pencegahan agar tidak terulang kembali nantinya..
Inti dari tujuan family group conferencing adalah mendapatkan kejelasan dari peristiwa yang terjadi dengan memberi semangat kepada pelaku, mengembalikan kerugian korban, melakukan reintegrasi korban ke masyarakat dan pertanggungjawaban bersama (Marlina, 2012).

d. Community Panel Meeting

Bentuk penyelesaian dengan cara mengadakan pertemuan yang dihadiri oleh tokok masyarakat, pelaku kejahatan, korban (bila mau) dan orang tua pelaku untuk mencapai sebuah kesepakatan perbaikan kesalahan.

Pasal 1 angka 6 UU SPPA merumuskan pengertian Keadilan Restoratif yaitu penyelesaian perkata tindak pidana dengan melibatkan pelaku, korban, keluarga pelaku/korban dan pihak lain yang terkait untuk bersamasama mencari penyelesaian yang adil dengan menekankan pemulihan kembali pada keadaan semula dan bukan pembalasan.

Keadilan restoratif yang dimaksud adalah kewajiban melaksanakan diversi. Dalam UU SPPA, keadilan restoratif diatur melalui diversi (Hiariej, 2016). Keadilan restoratif dalam UU SPPA diimplementasikan melalui diversi dalam menangani anak yang berkonflik dengan hukum. Hal ini sebagai upaya pemenuhan dan perlindungan hak-hak anak Indonesia sebagaimana terdapat dalam UUD 1945, Konvensi hak Anak, UU HAM dan UU Perlindungan Anak (Djamil, 2013). 
Keadilan restoratif bertujuan untuk melindungi hak-hak anak yang menjadi pelaku tindak pidana yang diwujudkan dengan adanya pelaksanaan diversi yang merupakan perwujudan keadilan dengan penyelesaian perkara di luar sistem peradilan pidana dengan melibatkan para pihak antara lain pelaku, korban, masing-masing keluarga yang bersangkutan, serta pihak terkait lainnya.

Menurut Pasal 1 angka 7 UU SPPA, diversi adalah pengalihan penyelesaian perkara Anak dari proses peradilan pidana ke proses di luar peradilan pidana. Kemudian, Pasal 8 ayat (1) UU SPPA menyebutkan bahwa diversi dilakukan melalui musyawarah yang melibatkan Anak dan orang tua/Walinya, korban dan/atau orang tua/Walinya, Pembimbing Kemasyarakatan, dan Pekerja Sosial Profesional berdasarkan pendekatan Keadilan Restoratif.

Adapun, tujuan dari diversi diatur dalam Pasal 6 UU SPPA yaitu:

a. mencapai perdamaian antara korban dan Anak;

b. menyelesaikan perkara Anak di luar proses peradilan;

c. menghindarkan Anak dari perampasan kemerdekaan;

d. mendorong masyarakat untuk berpartisipasi; dan

e. menanamkan rasa tanggung jawab kepada Anak.

Berdasarkan rumusan pasal mengenai definisi keadilan restoratif dan diversi tersebut di atas, terkesan bahwa sistem peradilan pidana anak mengandung pengertian bentuk mediasi penal, walaupun dalam UU SPPA tidak secara jelas menggunakan istilah mediasi.

Kemudian pada prinsipnya, UU SPPA menggunakan model restorative justice berupa dual track system menurut teori dari Van Ness karena penerapan restorative justice melalui diversi ditempatkan menduduki posisi primer sedangkan lembaga-lembaga formal berperan sebagai suatu unsur pendukung. UU SPPA mengimplementasikan prinsip restorative justice dalam konsep dual track system ini yaitu dengan mendahulukan penyelesaian perkara pidana anak melalui prinsip restorative justice melalui diversi terlebih dahulu baru apabila tidak tercapai mufakat maka penyelesaian tindak pidana masuk ke pengadilan dengan kata lain, sistem peradilan pidana akan tetap tersedia. Diversi dalam UU SPPA menggunakan dua pendekatan yakni pendekatan victim offender mediation dan pendekatan restorative conferencing. Pendekatan restorative conferencing baik meliputi family group conference(Hiariej, 2016).Victim offender mediation dalam hal, korban dan pelaku hadir bersama atau secara tidak langsung di mana korban dan pelaku dengan difasilitasi oleh mediator (shuttle mediation). Selain itu, dilihat dari sisi tujuan diversi yang diatur dalam Pasal 6 UU SPPA yakni "mencapai perdamaian antara korban dan Anak" dan "menyelesaikan perkara Anak di luar proses peradilan" menunjukkan kesan bahwa mediasi penal dengan bentuk Victim Offender Mediation (VOM) terkandung dalam sistem peradilan pidana anak. 
Restorative conference ditunjukkan dengan hadirnya pihak selain pelaku dan korban (yaitu keluarga dari masing-masing pihak). Dilakukan dengan pendekatan family group conferencing, yakni diversidengan cara keluarga kedua belah pihak (pelaku dan korban) membahas konsekuensi dari tindakan yang telah dilakukan dan pencegahan agar hal tersebut tidak terulang kembali, dengan memberi semangat kepada pelaku, mengembalikan kerugian korban, melakukan reintegrasi korban ke masyarakat dan pertanggungjawaban bersama. Tujuan dilaksanakannya mediasi penal (victim offender mediation) adalah memberi penyelesaian terhadap peristiwa yang terjadi, di antaranya dengan membuat sanksi alternatif bagi pelaku atau untuk melakukan pembinaan di tempat khusus bagi pelanggaran yang benar-benar serius (Marlina, 2012).

Dalam rangka mencapai keadilan restoratif, UU SPPA memberikan kewenangan kepada Penyidik, Penuntut Umum, dan Hakim untuk melakukan diversi terhadap anak yang berhadapan dengan hukum. Keadilan restoratif dapat diterapkan pada seluruh proses penegakan hukum pidana, tidak hanya pada satu proses saja, misalnya pada penyidikan atau penuntutan atau peradilan. Hal ini didasarkan pada prinsip keadilan restoratif masuk pada suatu sistem hukum pidana sehingga penerapannya ada pada setiap prosesnya dan juga tiap penegak hukum mempunyai kewenangan untuk menerapkannya. Penerapan diversi di semua tingkatan ini diharapkan mengurangi efek negatif (negative effect) keterlibatan anak dalam proses peradilan tersebut (Arief, 2001).

Hal ini diatur tegas dalam Pasal 7 ayat (1) UU SPPA bahwa diversi wajib diupayakan pada tingkat penyidikan, penuntutan dan pemeriksaan perkara anak di pengadilan negeri.

Diversi wajib diupayakan dalam tingkat penyidikan, penuntutan, dan pemeriksaan perkara anak di persidangan, meskipun konsekuensi "wajib" pada pengupayaan diversi juga menjadi kabur karena sanksi terhadap pengabaian ketentuan ini yang diatur pada Pasal 96 UU SPPA sudah dinyatakan bertentangan dengan Undang-Undang Dasar Tahun 1945 dan tidak mempunyai kekuatan hukum mengikat melalui Putusan Mahkamah Konstitusi Nomor 110/PUU-X/2012 (Ariani, 2014). Salah satu pertimbangan Mahkamah di dalam nomor (3. 18) adalah bahwa Pasal 96, Pasal 100, dan Pasal 101 UU SPPA menentukan ancaman pidana kepada pejabat khusus dalam penyelenggaraan SPPA, yaitu hakim, pejabat pengadilan, penyidik, dan penuntut umum, menurut Mahkamah, bukan saja tidak merumuskan ketentuan - ketentuan konstitusional mengenai kemerdekaan kekuasaan kehakiman dan independensi pejabat khusus yang terkait (hakim, penuntut umum, dan penyidik anak), yakni memberikan jaminan hukum bagi penyelenggaraan peradilan yang merdeka, tetapi lebih dari itu juga telah melakukan kriminalisasi 
terhadap pelanggaran administratif dalam penyelenggaraan SPPA yang tentu memberikan dampak negatif terhadap pejabat - pejabat khusus yang menyelenggarakan SPPA. Dampak negatif tersebut adalah dampak psikologis yang tidak perlu, yakni berupa ketakutan dan kekhawatiran dalam penyele nggaraan tugas dalam mengadili suatu perkara. Hal demikian menimbulkan ketidakpastian hukum dan ketidakadilan yang berarti bertentangan dengan Pasal 28D ayat (1) UUD 1945 dan kontra produktif dengan maksud untuk menyelenggarakan SPPA dengan diversinya secara efektif dan efisien dalam rangka keadilan restoratif;

Namun, tidak semua perkara pidana dapat diselesaikan menggunakan konsep restorative justice. Kasus kenakalan anak yang penyelesaiannya bisa dilakukan dengan konsep restorative justice bukanlah kasus yang mengorbankan kepentingan orang banyak dan bukan pelanggaran lalu lintas, tidak mengakibatkan hilangnya nyawa manusia, luka berat atau cacat seumur hidup dan bukan kejahatan terhadap kesusilaan yang serius yang menyangkut kehormatan (Marlina, 2012).

Menurut Pasal 7 ayat (2) UU SPPA, diversi hanya dapat diupayakan apabila ancaman pidana penjaranya di bawah 7 tahun dan bukan (recidive) pengulangan tindak pidana.

Hal tersebut telah sesuai dengan yang diatur dalam Rule 11 Beijing Rules (Standard Minimum Rules for the Administration of Juvenile Justice). Penjelasan dalam Commentary Rule 11 Beijing Rules, bahwa tindakan diversi khususnya ditujukan untuk tindak pidana yang tidak serius (the offence of non-serious nature). Namun selanjutnya dikemukakan, bahwa diversi itu tidak perlu dibatasi pada kasus-kasus kecil/ ringan, sehingga menjadikan diversi sebagai alat/instrumen penting (It need not necessarily be limited to petty cases, thus rendering diversion an important instrument).

Pasal 3 Peraturan Mahkamah Agung Nomor 4 Tahun 2014 tentang Pedoman Pelaksanaan Diversi Dalam Sistem Peradilan Pidana Anak menegaskan bahwa pengupayaan diversi oleh hakim anak wajib dilakukan apabila ancaman tindak pidana pidana penjara di bawah 7 (tujuh) tahun dan yang diancam dengan pidana penjara 7 (tujuh) tahun atau lebih, dalam bentuk surat dakwaan subsidaritas, alternatif, kumulatif, maupun kombinasi (gabungan).

Menurut Zenny Rezania Dewantary, mengenai pembatasannya, di satu sisi, batas 7 (tujuh) tahun yang memisahkan wajib diversi dan yang tidak wajib diversi, menunjukkan keinginan untuk kepastian hukum untuk tindak pidana yang dianggap berat (menurut undang-undang) atau merupakan pengulangan tindak pidana, sekalipun pelakunya adalah anak. Di sisi lain, untuk sejalan dengan keadilan restoratif, upaya diversi diwajibkan di tiap level pemeriksaan. Artinya diversi adalah wajib, tapi wajib terbatas (Dewantary, 2016) 
UU SPPA memberikan pembatasan bahwa kewajiban diversi hanya untuk perkara pidana yang memiliki ancaman pidana di bawah 7 (tujuh) tahun, artinya untuk perkara pidana yang diancam dengan 7 (tujuh) tahun penjara atau lebih, dan/atau merupakan pengulangan tindak pidana, penegak hukum tidak wajib menawarkan upaya diversi. Sifat wajib yang dimaksud UU SPPA adalah kewajiban bagi penegak hukum untuk menawarkan. Pasal 7 ayat (2) dengan sendirinya menutup kesempatan diversi bagi tindak pidana dengan ancaman pidana penjara 7 (tahun) atau lebih, sehingga pelakunya akan diperiksa di pengadilan melalui prosedur acara pidana konvesional.

Seperti yang telah dijelaskan bahwa "diupayakan" dalam hal ini mempunyai makna "ditawarkan" alternatif penyelesaian melalui diversi. Menawarkan pengupayaan diversi dalam hal ini merupakan kewajiban bagi penegak hukum.

Pasal 9 ayat (2) UU SPPA juga memberikan pembatasan lainnya yakni dalam hal melakukan kesepakatan diversi, tetap harus mendapatkan persetujuan sekaligus kesediaan pihak korban dan/atau keluarga Anak Korban, kecuali untuk tindak pidana berupa pelanggaran, tindak pidana ringan, tindak pidana tanpa korban atau apabila nilai kerugian yang dialami korban tidak melebihi nilai upah minimum provinsi setempat.

Hal itu menunjukkan bahwa pada dasarnya, diversi yang wajib pun tetap bergantung pada kehendak pihak korban untuk menggunakan jalur diversi atau tidak. Tindak pidana yang dikecualikan dalam pasal 9 ayat (2) UU SPPA, kewajiban diversi hanya sampai pada pengupayaannya oleh penegak hukum di level pemeriksaan terkait. Diversi adalah wajib diupayakan, tetapi pelaksanaannya, apakah akan ditempuh diversi atau tidak, tergantung kesepakatan dari pihak pelaku dan korban. Dalam hal ini sangat terlihat diversi pada prinsipnya adalah wajib, tapi wajib terbatas (Dewantary, 2016). Adanya syarat perdamaian antara para pihak terutama harus dengan persetujuan dari pihak korban untuk menerima kesepakatan penyelesaian kasus anak dengan upaya musyawarah diversi.

Setelah dilakukannya proses diversi, maka muncul kesepakatan diversi yang bentuknya diatur dalam Pasal 10 ayat (2) UU SPPA berupa pengembalian atau penggantian kerugian dalam hal ada korban; rehabilitasi medis dan psikososial; penyerahan kembali kepada orang tua/Wali; keikutsertaan dalam pendidikan atau pelatihan di lembaga pendidikan atau LPKS paling lama 3 (tiga) bulan; atau pelayanan masyarakat paling lama 3 (tiga) bulan.

Disamping itu, muncul pula hasil kesepakatan diversi dalam hal perkara yang diupayakan diversi dan diversinya berhasil yang berbentuk, antara lain adanya perdamaian dengan atau tanpa ganti kerugian; penyerahan kembali kepada orang tua/Wali; keikutsertaan dalam pendidikan atau pelatihan di lembaga pendidikan atau LPKS paling lama 
3 (tiga) bulan; atau pelayanan masyarakat.

Kemudian, berdasarkan Pasal 12 ayat (2), Pasal 29 ayat (3), Pasal 42 ayat (3), Pasal 52 ayat (5) UU SPPA, hasil kesepakatan diversi harus diajukan penyidik/penuntut umum/hakim ke ketua Pengadilan Negeri untuk memperoleh "penetapan", dan setelah menerima penetapan, Penyidik/ Penuntut Umum menerbitkan penetapan penghentian penyidikan atau penetapan penghentian penuntutan.

Apabila diversi gagal karena tidak mencapai kesepakatan atau sejak awal tidak dapat diupayakan diversi dalam penyelesaian perkara anak, maka proses peradilan pidana dilanjutkan ke tahap selanjutnya hingga pada tahap persidangan sesuai yang diatur dalam Pasal 13 UU SPPA.

Mengingat UU SPPA mengandung konsep dual track system ini yaitu dengan mendahulukan penyelesaian perkara pidana anak melalui prinsip restorative justice melalui diversi terlebih dahulu baru apabila tidak tercapai mufakat maka penyelesaian tindak pidana masuk ke pengadilan dengan kata lain, sistem peradilan pidana akan tetap tersedia.

Mengenai ketentuan pidana, diatur dalam Pasal 96, 97, 98, 99, 100 dan 101 UU SPPA yang pada intinya berisi ancaman pidana terhadap aparat penegak hukum yang meliputi penyidik, jaksa dan hakim dalam hal apabila tidak melakukan kewajibannya untuk mengupayakan diversi dalam penyelesaian perkara anak. Namun Pasal 96, 100 dan 101 tidak lagi mempunyai kekuatan hukum mengikat dengan adanya Putusan Mahkamah Konstitusi Nomor 110/PUU-X/2012 karena bertentangan dengan UUD NRI 1945. Begitupun juga Pasal 99 UU SPPA yang tidak lagi mempunyai kekuatan hukum mengikat dengan adanya Putusan Mahkamah Konstitusi Nomor 68/PUUXV/2017.

\section{Kesimpulan}

Sistem peradilan pidana anak wajib mengutamakan pendekatan keadilan restorative yang diatur melalui diversi. Dalam sistem peradilan pidana anak mengandung pengertian bentuk "mediasi penal", dengan dua pendekatan yakni victim offender mediation dan restorative conferencing yang meliputi family group conference.

Mengenai pembatasan pemberlakuannya, UU SPPA sendiri memberikan pembatasan yakni diversi hanya dapat diupayakan untuk perkara pidana yang memiliki ancaman pidana di bawah 7 (tujuh) tahun dan bukan merupakan pengulangan tindak pidana. Selain itu, diversi harus dengan persetujuan dan kesediaan dari pihak korban.

\section{Daftar Pustaka}

Ariani, Nevey Varida. (2014). Implementasi Undang-undang Nomor 11 Tahun 2012 Tentang Sistem Peradilan Pidana Anak Dalam Upaya Melindungi Kepentingan Anak, Jurnal Media Hukum, Vol. 21 (No.1), pp. 107122.

Arief, B. N. (2008). Bunga Rampai Kebijakan Hukum Pidana (Perkembangan Penyusunan 
Konsep KUHP Baru). Jakarta: Kencana Prenada Media Group.

Arief, Barda Nawawi. (2001). Beberapa Aspek Kebijakan Penegakan dan Pengembangan Hukum Pidana. Bandung: Citra Aditya Bhakti.

Burhanuddin. (2019). Tinjauan Yuridis Tindak Pidana Yang Dilakukan Oleh Anak Dibawah Umur (Studi Kasus Putusan No.1/Pid.Sus-Anak/2017/PN Mll), Al-Risalah, Vol. 19 (No.1), pp. 23-34.

Chandra, Septa. (2014). Politik Hukum Pengadopsian Restorative Justice Dalam Pembaharuan Hukum Pidana, Fiat Justisia Jurnal Ilmu Hukum, Vol. 8 (No. 2), pp. 255-277.

Disemadi, Hari Sutra, dan Kholis Roisah. (2019). Kebijakan Model Bisnis Bank Wakaf Mikro Sebagai Solusi Pemberdayaan Ekonomi Masyarakat. Law Reform, Vol 15 (No.2), pp. 177-194.

Dewantary, Zenny Rezania. (2016). Keadilan Restoratif dan Pembatasan Diversi Pada Undang-Undang 11 Tahun 2012 Tentang Sistem Peradilan Pidana Anak, Veritas et Justitia, Vol. 2 (No. 2), pp. 303-326.

Disemadi, Hari Sutra, dan Kholis Roisah. (2019). Urgency of the Contempt of Court Criminalization Policy to Overcome Harassment Against the Status and Dignity of Courts." Brawijaya Law Journal Vol. 6 (No. 2), pp. 224-233.

Djamil, M. Nasir. (2013). Anak Bukan Untuk Dihukum. Jakarta: Sinar Grafika.
Hiariej, Eddy O.S. (2016). PrinsipPrinsip Hukum Pidana (Edisi Revisi). Yogyakarta: Universitas Atmajaya.

Hutahuruk, Rufinus Hotmaulana. (2013). Penanggulangan Kejahatan Korporasi Melalui Pendekatan Restoratif (Suatu Terobosan Hukum). Jakarta: Sinar Grafika.

Manan, Bagir. (2008). Restorative Justice (Sebuah Perkenalan) dalam Refleksi Dinamika Hukum Rangkaian Pemikiran dalam Dekade Terakhir. Jakarta: Perum Percetakan Negara Indonesia.

Marlina. (2012). Peradilan Pidana Anak di Indonesia: Pengembangan Konsep Diversi dan Restorative Justice. Bandung: PT. Refika Aditama.

Nashriana. (2012). Perlindungan Hukum Pidana bagi Anak di Indonesia. Jakarta: PT. Raja Grafindo Persada.

Retnaningrum, Dwi Hapsari. (2013). Restorative Justice dalam Kasus Malpraktik (Makalah Seminar Nasional, Membangun Sistem Hukum Pidana Berbasis Budaya Hukum Nasional), Purwokerto: Fakultas Hukum Universitas Jenderal Soedirman.

Soetedjo, Wigiati. (2010). Hukum Pidana Anak Cetakan Ketiga. Bandung: Refika Aditama. 